\title{
THE CHALLENGES IN IDENTIFICATION OF ARTISTS-MANAGERS: CONSEQUENCES FOR CREATIVITY
}

\author{
Michał SZOSTAK (D) ${ }^{1,}{ }^{*}$, Łukasz SUŁKOWSKI ${ }^{2}$ \\ ${ }^{1}$ Faculty of Management and Security, University of Social Sciences, \\ ul. Łucka 11, 00-842 Warszawa, Poland \\ ${ }^{2}$ Faculty of Management and Social Communication, \\ Institute of Public Affairs, Jagiellonian University, \\ ul. Gołębia 24, 31-007 Kraków, Poland
}

Received 26 October 2020; accepted 20 March 2021

\begin{abstract}
Research on identity, its tensions and paradoxes have extensive literature and a large number of scientists exploring the subject. Our own experiences in the fields of art and management were the main arguments for the introduce of the concept of "artists-managers" and to undertake research in the area of artists-managers' identity to find the conclusions for creativity. This article aims to describe the challenges in the identification of artists-managers, who can be crucial in understanding the creativity factor. To reach our goal, we run empirical qualitative research based on in-depth interviews with key-informants from Europe, Africa and North America as well as auto-analysis of an artist-manager identity. We answer the research question "Who is the artist-manager?". We present our "creativity development model" on the base of artists-managers' characteristics and we describe what kind of challenges should be considered in the empirical research of artists-managers. These challenges may be used as guidelines for artists-managers: for those who discover an artist-manager in their personality, for defined artists-managers to help to better understand their features, and for artists-managers' followers to be more sensitive for their leaders' characteristics. Our model may help to understand and develop the creativity of society.
\end{abstract}

Keywords: artist's identity, artist-manager's identity, creativity, identity tension, manager's identity, paradoxical thinking, self-construction.

\section{Introduction}

Manager's identity research has an extensive literature and a large number of scientists explore this subject deeply. Since the beginning of the 21 st century, it is possible to observe an increase in the number of research and publications about two or more identities of an individual searching for and exploring additional values, tensions and paradoxes on the base of the identities of policemen (Ahuja et al., 2017), architects (Cuganesan, 2017), physicians (Netting \& Williams, 1996), medics (Joffe \& MacKenzie-Davey, 2012), air traffic sector employees (Hallier, 2004), general professionals (Bulei et al., 2014), or artists (Hracs, 2015;

\footnotetext{
${ }^{\star}$ Corresponding author. E-mail: mszostak@san.edu.pl
} 
Tchouikina, 2010; Zambrell, 2016). Since identity is a very complex issue to analyse, researchers reveal many optics trying to describe the concept possibly accurately: personal identity (Mochalova, 2020; Thornton, 2011; Zambrell, 2016) versus group (Vincent \& Kouchaki, 2014) or collective identity (David \& Bar-Tal, 2009; Khazraee \& Novak, 2018). Among group identities, there are researches about organizational identity (Erat et al., 2020), social identity (McNeill \& Venter, 2019; Sethi et al., 2010), national identity (Grigoryan \& Kotova, 2018; Saavedra Llamas \& Grijalba de la Calle, 2020). Focusing on the area of an individual's activities, we may speak about professional identity (Kunrath et al., 2020; Zocche et al., 2018). Adding ethics optics, we can define a moral identity (Gerpott et al., 2019). Identity may be developing (Yazar \& Arifoglu, 2012) by identity work (Bennett \& Hennekam, 2018; Reedy, 2008), established (Erat et al., 2020) or sustainable (McNeill \& Venter, 2019). There are also identity management strategies (Grigoryan \& Kotova, 2018) or narrative identities (Gray et al., 2015; Sveningsson \& Alvesson, 2003; Wolf, 2019) assisting managers to reach specific objectives. Particular types of identity, e.g. creative identity (Vincent \& Kouchaki, 2014), or dialogical identity (Masso, 2010) may help to underline the constantly moving aspect of identity. Finally, depending on the complexity, we can distinguish a simple (separate) identity, e.g. manager's identity (Hallier, 2004; Watson, 2009) and artist's identity (Dahlsen, 2015), or a complex identity (David \& Bar-Tal, 2009). Our own - both practical and theoretical experience in the fields of art and management was the main argument for introducing the concept of "artists-managers" and conduct research in the area of artists-managers as one coherent field. In management practice, many artists manage various types of arts organizations (Elstad \& Jansson, 2020); there is also a group of people, who are both professional artists and professional managers, but in different environments, and with great success in both areas. It seems that the artist-manager's identity should reveal interesting conclusions in the area of creativity.

This article aims to describe the challenges in the identification of artists-managers. After analysing different approaches to the basic concepts of the field from the literature (artist's identity, manager's identity), we will: 1) answer the research question "Who is the artist-manager"?; 2) present our model of creativity development built on the base of the identification process of artists-managers picturing the main issues for creativity development referring to the characteristics of artists-managers' identity and 3) describe what kind of challenges should be considered in the empirical research of artists-managers, their identity and creativity in general. These challenges may be used as practical guidelines for artists-managers: a) for those who are discovering an artist-manager in their personality, b) for defined artistsmanagers to help to understand their features better, c) for artists-managers' followers to be more sensitive for their leaders' characteristics, as well as for d) creativity researchers.

\section{Methodology}

We used the method of exploratory research to clarify the exact nature of the problem of artists-managers' identity. Firstly, secondary research in the form of reviewing literature and data was conducted. Secondly, formal qualitative research through in-depth interviews was conducted. Our previous theoretical analyses applying aesthetical theories into management 
area - i.e. aesthetical situation, creative personality types, which can be combined in the metaphor of "an organisation as an artwork" (Szostak \& Sułkowski, 2020b), as well as describing the borders of artistic activities by defining the managerial kitsch phenomenon (Szostak \& Sulkowski, 2020a) - were setting the background for this research. Our empirical qualitative research based on in-depth interviews with key-informants (artists-managers) from an international environment: Bulgaria, Nigeria, Poland, Ukraine, the United Kingdom (UK) and the United States (US) was conducted in February - March, 2020. We examined people who are/were both artists and managers in their professional life. The research sample was not limited to persons who currently play both roles at the same time; among the respondents, some people played both roles at different periods of their lives, to varying degrees and at different levels. We asked 33 artists-managers for participation in the research; finally, 22 of them agreed to take part in the project; those, who did not finally take a part in the research, said that they did not consider themselves as artists or managers, although - according to our research requirements - they met the criteria completely.

The majority of the sample was from Poland ( $n=12,55 \%)$, three from the US (14\%), two from the UK (10\%), one person from Bulgaria, Nigeria and Ukraine (4.5\% each). Furthermore, the majority of the respondents were men $(n=16,73 \%)$, have experienced in the music field ( $\mathrm{n}=18,82 \%)$, and most of the sample have no formal managerial education $(\mathrm{n}=$ $15,68 \%$ ). There was no effort to achieve a balance in the area of sex or age of the participants, neither we did not balance the sample according to their professional experience length nor their chosen art form. We are fully aware of the impact of these elements on the research results but - due to the pilot character of this study - we continued with the findings and the results. We publish the results of this research here and in other journals too.

\section{Literature review}

The literature review methodology was based on a qualitative choice of the literature taken from the following databases: EBSCOhost, Google Scholar, JSTOR and Scopus. The methodological approach was based on an interdisciplinary and multi-paradigm approach taking into account the publications from the areas of art (artist's identity), management (manager's identity) and psychology (identity tensions, paradoxical thinking).

\subsection{Identity, tensions, paradoxes}

The distinguishing character or personality of an individual with underlining elements of "who a person is, or the qualities of a person or group that make them different from others" are the main elements of the identity definition. Because an individual does not have a single identity and possesses several different identities, it develops different facets of its identities in different settings (Berthoin Antal et al., 2016); that is why individuals are subjected to contradictory pressures. Identity should be seen as a social process (becoming) rather than something characterized by absolutism (being). Identity is an endless process, becoming stable only in certain conditions (Bulei et al., 2014; Hay, 2014). The dynamics between identity (who I am) and anti-identity (who am I not) is crucial in understanding the challenges of identification (Carroll \& Levy, 2008). 
Dutton et al. (2010) described the work-related identities in a four-perspective typology capturing "positive" identities. Each perspective on positive identity (virtue, evaluative, developmental, structural) highlights a different source of positivity and opens new ways for theorizing about identity construction. In organizational contexts, characterized by multiple logics spanning from conformity to innovation, people experience tensions between different identities; tensions between the managerial and the artistic identities are one of the areas (Adler, 2011, 2015; Gotsi et al., 2010; Schein, 2001). Identity tensions are intensified in the contexts of change and uncertainty (White, 1992). Managers who impose paradoxical demands on employees are likely to generate defence mechanisms. Splitting the two poles rather than integrating the tensions impede the employees' capacity to be creative (Berthoin Antal et al., 2016; Giraud Voss et al., 2006). Artists and managers use adaptive skills; they can do their work everywhere because it involves the creative use of the "real world" to implement ideas from the "world of values" (Szostak, 2020); this is confirmed by the fact that artists and managers work in all economic conditions and systems, perfectly adapting to deep and fast changes (Tchouikina, 2010). Artists do not feel tensions between their identities, that is why they are perfect patterns for managers who work in organisations with these tensions (Adler, 2015; Schediwy et al., 2018).

Paradoxical thinking is a process in which an individual identifies and defines contrasting personal characteristics to bring about their positive aspects. The paradox involves contradictory elements that are present and operate equally at the same time. People who use their contradictory characteristics can bring about positive results more than those who are trying to find a calm balance. Like a musician who must be focused on his public performance, but also needs to be relaxed at the same time, because the muscles tightened nervously will not allow him to get the most out of it; he cannot have a balance between the two states of relaxation and muscle engagement but must work at the same time to maintain full relaxation in muscles and full focus on the matter of performing. Paradoxical thinking problem solving requires a thorough self-analysis to discover the most positive ways of expressing our personal characteristics (DeFillippi et al., 2007; Fletcher \& Olwyer, 1997; Knight \& Paroutis, 2017; Putnam, 2015).

\subsection{Artist's identity}

Artist's identity has been developing from the beginnings of humanity. Following identities can be found: a doer, a God's will doer (Tatarkiewicz, 2020), an artisan, a master, a genius, a holy man in touch with the unseen, a cultural aristocrat, a professional, a knowledge worker, an entrepreneur (Deresiewicz, 2015), an influencer, a freedom maker (Hermes et al., 2017), an artist by vocation, a value/idea guardian, and a superman. Using dichotomous differentiated dimensions of creativity and efficiency, we can find the following artist's identities: a conceptualist, a copyist, an artistic craftsman (artisan) and a creator (Szostak \& Sułkowski, 2020b). The differences between an artist's identity and the perception of an artist's role should be underlined here. 


\subsection{Manager's identity}

Literature shows the following manager's identities: an organiser, a political operator (Watson, 2009), an expert (Bulei et al., 2014), a rational actor (Sims, 2003; Watson, 1994). Using dichotomous differentiated dimensions of creativity and efficiency, we can find the following manager's identities: a manager-theoretician; an administrator (an official), a professional, a creative manager (a leader). A manager with high creativity and proficiency in his field can be successfully called a management artist; it will also be authorized to name the manager as an artist/virtuoso who, realizing his visions, knows how to organize reality according to his intentions (Szostak \& Sułkowski, 2020b). There is also a group of identities of kitsch managers, but it is more an issue of external description rather than self-conception. Among them, we find a self-styled management guru, a narcissistic manager and a mendacious manager who underlines his personal goals above the goals of the organisation (Szostak \& Sulkowski, 2020a).

Management can be conceptualized in terms of the tension between identity-regulation and identity-work (Alvesson \& Willmott, 2002; Warhurst \& Black, 2017; Watson, 2009). Identity work involves a conversation between internal ideas, wishes and affections and external images and evaluations (Ibarra, 2004; Sveningsson \& Alvesson, 2003). Watson (1994) described the double control problem where managers work to manage the self while simultaneously being expected to manage the activities and thinking of colleagues. The identity tensions in organizations should be managed wisely. Because there are differences in how tensions are interpreted across organisational levels, the role of the top management team leader's practices becomes crucial. Researchers' interest is mainly focused on the description of the identity of a manager who is facing seemingly opposite issues; in this area identity tensions and paradoxical thinking are often recognized. The most-discussed tensions in the cultural and creative industries are those between art and commerce, creativity and business, the artistic and the economic logic (Schediwy et al., 2018; Zachorowska-Mazurkiewicz \& Sierotowicz, 2017; Kačerauskas, 2018; Stasiulis, 2017).

\subsection{Artist-manager's identity}

There is not much about the identity of an artist-manager in the literature. Only one theoretical research shows the mutual (common and different) relations of the artist's and manager's identities (Szostak \& Sułkowski, 2020b). Similarities include: 1) the fact that artists and managers begin creative activities in the non-material sphere (conceptual phase), and then implement ideas/goals in the material sphere; 2 ) both - without a specialized education - can function well in their fields. Among the differences it should be noted that: 1) the manager can be satisfied with the "slightly better" results; the artist always refers to and strives for the ideal; 2) manager's utilitarianism is inherently contrary to the artist's creative freedom despite the fact that both of them pursue specific goals; 3 ) some artistic (musical) works live in time only, while organizations function in time and space; 4) a classical artwork does not evolve; organizations evolve; 5) artists - with artistic creation - rarely worry about the financial result of the entire artistic undertaking; they have administrative directors (philharmonics, theatres, galleries) for this purpose; in turn, a manager usually has to consider the aspect of financial effectiveness of his work; 6) the artist (writer, painter, musician) works in art on his individual basis, although 
his interpersonal-organizational skills are not insignificant; manager works as a team - he is more of an orchestra conductor or director of the performance. Using dichotomous differentiated dimensions of creativity and efficiency, we can find four artists-managers' identities: a visionary - a person with high creativity and low organizational efficiency; a reproducer - low creativity and low organizational efficiency; a craftsman - low creativity and high organizational efficiency; a creator - high creativity and high organizational efficiency (Szostak \& Sułkowski, 2020b). It should be noted here that the art of design may be an important source of methods for the science of management. Design thinking discipline, being art itself, offers methods (the inner need for innovation and originality, constantly looking for creative solutions) that artistsmanagers can use in their practice (Hospers \& van Dalm, 2005; Martin et al., 2015).

\section{Results}

Referring to our respondents, the special features of a person who is both a manager and an artist are: "The ability to make decisions and be a leader, always being open to try to understand the other person you are working with"; "Being honest and working with integrity"; "Better understanding of self and others by using both right and left brain-sides"; "Multitasking, universalism, flexibility"; "Having ability to do different activities at the same time"; "Being more interdisciplinary"; "Being more sensitive to impulses from the world; seeing more; behave more rationally, because of not wasting resources, energy and time on actions that will not bring the expected results; being more creative; being able to find an unconventional solution in every situation"; "Being usually more imaginative than those who are not artists; in addition, having in their life a sphere of professional satisfaction other than managerial, they are more open and contented"; "Being more versatile, have a very strong ego"; "Being super hardworking and extremely mentally resistant".

Respondents show the following similarities between managerial and artistic activities: honesty, integrity, paying attention to details, being organized and persistent, strategic thinking, establishing perfect contact with the audience/organisation, recognizing contexts and responding to them appropriately, permanent consideration of the human factor, being alone in the final decisions. Features of artists-managers are: self-discipline, imagination, broad experience, dedication, perseverance in pursuing goals and multi-faceted activities, ability to project work, discipline in achieving goals, ingenuity, commitment, passion, determination, creativity, perfect communication with the recipient, high ability to promote and present, devotion, patience, absolute diligence and full commitment, consistency.

The skills developed in artistic work and used in managerial activities were named as patience, calmness, integrity, honesty, creativity, being surprised, risky, sometimes irrational, emotional sensitivity, ability to communicate expressively, self-control, simplicity, consistency in action, self-discipline, proper organization of time, punctuality, responsibility, concentration, empathy, interpersonal skills.

The skills developed in managerial activity and used in artistic creation are: planning several months ahead, being organized, being pragmatic, using theories, being able to appreciate structure and formality, initiative, imagination, interpersonal skills, self-discipline and teamwork, attention to detail and general impression, diplomatic skills, negotiation, self-presentation, 
control stress and emotions. Some answers were more complex. "Paradoxically, the basic and universal features of good work are important in both areas. The individual approach and character traits are important". "Both identities - being deeply internalized - interpenetrate and it is difficult to distinguish which of the features/skills comes from which identity; maybe they result from character traits and these character traits determine being an artist and a manager?".

Around half of respondents do not experience paradoxical situations in professional life between the artist's and the manager's identities. "I believe those two areas of my professional life affect each other. I believe my managerial skills are uniquely formed by my work as a musician, and my approach as a manager is entirely different from other editors and publishers in the company". Those who experienced paradoxical situations said: "All the time; all I want to do is practice organ but I have to manage details of many non-musical projects as well, as a means of making money"; "Most often when I perform the functions of a contractor and manager for myself". "Usually, when one enters the managerial path - in public perception it obscures the artistic image. The artist's schematic (untrue) image is an unorganized man, 'with his head in the clouds'. Being a manager and an artist in the perception of other people can be seen as mutually exclusive. I met opinions that if I'm a good manager, I'm probably not a good artist and vice versa. But for me there is no contradiction". Two respondents experienced paradoxical situations occasionally: "When I might want something artistically but can't allow it managerially (resources)", "I envy my colleagues who are only artists that they are not aware of the administrative kitchen".

When seeking a solution in a paradoxical situation in professional life, the dominant identity depends on the situation, place and task: "It is impossible to explicitly support the domination of one of them", "These identities are interchangeable in various situations"; "It depends on the context and nature of the problem. Rather, it is a matter of seeking a compromise between the suggestions of both identities. I don't change from the artist's optics to the manager's optics, but I work with both optics in parallel". These answers argue that the artist-manager identity can be perceived as one coherent piece.

The majority of the respondents do not experience tensions between the artist's identity and the manager's identity in professional life or they solve this problem unconsciously. "I think I have striven to make these two spheres of my life compatible. It seems to have been an outgrowth of the demand of multi-tasking and, in essence, working at both jobs on the same days". "It seems to me that I can separate these functions quite well and I try to make these two attitudes complement and support each other, which often happens". "I experience the parallel 'voices' of both opticians, which I then try to combine into one coherent message for myself and the environment". "I have no problem with seeing myself as both a manager and an artist at the same time; each of us works in our lives in different areas; I am one, full man who has responsibility for everything he chooses as a field of his activity".

Our respondents undertake the following methods to avoid the problem of arising identity tensions: "Sitting back and relaxing", "Going the gym several times a week", "Putting off doing managerial activities and dedicating time to [artistic] practising", "Taking my time", "Playing chess or video games, watching TV", "Doing intellectual analysis with a rational approach to factors, weighing them and making conscious decisions; looking from a distance without time pressure, sleeping with the problem", "Listening to music". 


\section{Discussion}

On the base of our research, the shortest definition of the identity of an artist-manager will be as follows: a person who - for a creative reason - uses paradoxical thinking towards tensions based on (at least artistic and managerial) identities after the process of identification of these identities. After the literature analysis and results of the interviews, it can be stated that all crucial elements described above - i.e. identity, identification, identity tensions and paradoxical thinking - can be combined in one coherent piece, where the development of creativity is the main benefit and the main accelerant. There is only one condition for keeping those elements together, i.e. the awareness of the final goal and the perseverance in solving current problems. On the base of our study, we created the "creativity development model" (see Figure 1).

To answer the basic question of what makes a person undertake the creative activity, we must refer to the achievements of aesthetics, which developed concepts of "basic personality" and "creative personality". The creative personality is a selection of basic personality traits that condition the start of creative activity, its continuation and gives shape to the final work (Gołaszewska, 1984; Szostak, 2020; Szostak \& Sułkowski, 2020b). Referring to our model, the creative personality needs to meet at least two identities and start the identity work in the form of identification. Different identities, work on the identification process and the need for solving a problem, create tensions between opposite features and goals of identities. At this moment, the individual should focus the streams of approaching problems in an orderly and understandable (for him/her) way to avoid negative, intrinsic consequences of these tensions. While maintaining and managing identity tensions, the process of paradoxical thinking should be launched. Identity tensions should not be reduced because they are the main catalyst for creativity; the individual should learn to live with tensions and use them creatively (just as a musician does not fight opposite goals of muscle flexibility and full concentration during the public performance). To close up this circle, it can be said that creative activities develop and teach the individual to understand its creative personality. With each cycle of the model, the identity of the artistmanager is more reworked and coherent and the individual develops his creativity.

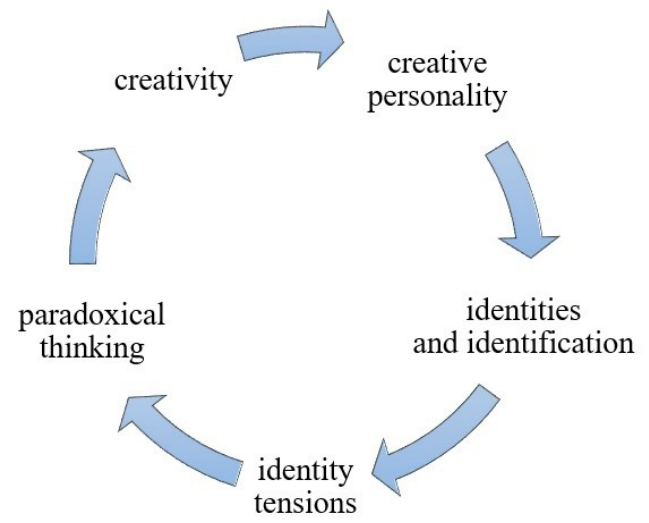

Figure 1. Creativity development model (source: created by authors) 
While struggling with artists-managers' identification, we found the main following challenges which should be named and developed: a) varying degrees of self-knowledge; even if an individual is a great professional in one or both areas, it does not mean that $\mathrm{s} / \mathrm{he}$ is able to describe her/his identity; self-knowledge is another ability which should be developed to allow an artist-manager to talk about his complex identity; b) reluctance to personal ascend especially if there are negative aspects to describe; c) denial/modelling mechanisms; these psychologically defined mechanisms are used by individuals to reshape the way they are their perceived by their identity; d) social validation mechanism; it is used by individuals to validate their identity using the audience; while the research is based on the ground of delicate elements of personalities we can be sure that answers will be affected by this mechanism; e) respondent's (un)confidence in the researcher; speaking naked truth about their deeply hidden personal features and motifs is not an easy task for many of us; f) inability to use quantitative research; because being an artist-manager is not a common phenomenon, the research can be conducted with the use of qualitative methodology only; another fact is that artists-managers are more personalities than just "regular" people; g) different positions of each individual on the artist-manager scale; different identities as an artist and as a manager imply many possibilities of identity as artist-manager; $h$ ) these personalities should not be imitated thoughtlessly, because every artist-manager is different; they should rather be examples of people who deal with problems using special methods.

Exploring the intra-psychic features of the research participants while having the researcher's knowledge and experience in the researched field was crucial to understanding delicate mental issues and optics because individuals reshape their answers according to monitoring their self-perception (Brown, 1990).

\section{Conclusions}

As we believe, there are three practical objectives from our study: 1) the detailed description of the identity of artists-managers who are a separate group of managers among artists and artists among managers; 2) the creativity development model which organize all issues of identity and identification around creativity, being the crucial factor of organisation's development; this model can be fully applied to better understanding and development of creative society; 3 ) the list of challenges important in the understanding of artists-managers' identity. The elements described above should help to reduce "the pain" of intra-psychic tensions and influence paradoxical thinking as a crucial step toward the development of creativity. The ability to understand and manage tensions and paradoxes in organisations can also improve creativity and reduce negative consequences for personalities. It should be recognized that the artist's identity must be able to consciously control the process of a natural drift towards kitsch, to which management efficiency and effectiveness always aim (Szostak \& Sulkowski, 2020a); in turn, the manager's identity can perfectly support unhampered creativity in effective strategic, project, time or finance management (Child, 2012). In this approach, the artist-manager's identity should be the most desirable asset of today's organisation. The artistmanager identity also opens a range of possibilities of its use and further development in many contexts e.g. in creative industries. 
Among the limitations of our analysis we need to indicate that there are not many artistsmanagers among artists and managers, that is why the research area is small; but this group can make an important contribution to research on creativity.

Among perspectives there is a need for detailed research on the differences between the identity and the self-perception of artists-managers; it should reveal an important contribution to our creativity development model. Quantitative research of the perception of artists, managers and artists-managers can also reveal new horizons in understanding the differences between the perception of artists-managers by the different groups of society and the identity of artists-managers.

\section{Acknowledgements}

We want to thank all interviewees who take part in the research during the beginning of the COVID-19 pandemic.

\section{References}

Adler, N. J. (2015). Finding beauty in a fractured world: art inspires leaders - leaders change the world. Academy of Management Review, 40(3), 480-494. https://doi.org/10.5465/amr.2015.0044

Adler, N. J. (2011). Leading beautifully: the creative economy and beyond. Journal of Management Inquiry, 20(10), 1-14. https://doi.org/10.1177/1056492611409292

Ahuja, S., Nikolova, N., \& Clegg, S. (2017). Paradoxical identity: the changing nature of architectural work and its relation to architects' identity. Journal of Professions and Organization, 4(1), 2-19. https://doi.org/10.1093/jpo/jow013

Alvesson, M., \& Willmott, H. (2002). Identity regulation as organizational control: producing the appropriate individual. Journal of Management Studies, 39(5), 619-644. https://doi.org/10.1111/1467-6486.00305

Bennett, D., \& Hennekam, S. (2018). Self-authorship and creative industries workers' career decisionmaking. Human Relations, 71(11), 1454-1477. https://doi.org/10.1177/0018726717747369

Berthoin Antal, A., Debucquet, G., \& Fremeaux, S. (2016). Addressing identity tensions through paradoxical thinking: lessons from artistic interventions in organizations. Management International/ International Management, 21(1), 25-40. https://doi.org/10.7202/1052495ar

Brown, J. D. (1990). Evaluating one's abilities: shortcuts and stumbling blocks on the road to selfknowledge. Journal of Experimental Social Psychology, 26(2), 149-167. https://doi.org/10.1016/0022-1031(90)90073-U

Bulei, I., Mihalcioiu, V., \& Tucmeanu, A. (2014). The professional vs. the manager-identity issues and key features. Valahian Journal of Economic Studies, 5(3), 31-36.

Carroll, B., \& Levy, L. (2008). Defaulting to management: leadership defined by what it is not. Organization, 15(1), 75-96. https://doi.org/10.1177/1350508407084486

Child, D. (2012). The artist as project manager: Thomas Hirschhorn's "Bataille Monument". Journal of Arts and Communities, 4(3), 217-230. https://doi.org/10.1386/jaac.4.3.217_1

Cuganesan, S. (2017). Identity paradoxes: how senior managers and employees negotiate similarity and distinctiveness tensions over time. Organization Studies, 38(3-4), 489-511.

https://doi.org/10.1177/0170840616655482 
Dahlsen, J. (2015). An environmental artist and PhD candidate's observations of globalism's post GFC aftermath: is there economic viability, for marginalised artists creating the culture of environmental sustainability? Creative Approaches to Research, 8(1), 97-131.

David, O., \& Bar-Tal, D. (2009). A sociopsychological conception of collective identity: the case of national identity as an example. Personality and Social Psychology Review, 13(4), 354-379. https://doi.org/10.1177/1088868309344412

DeFillippi, R., Grabher, G., \& Jones, C. (2007). Introduction to paradoxes of creativity: managerial and organizational challenges in the cultural economy. Journal of Organizational Behaviour, 28, 511-521. https://doi.org/10.1002/job.466

Deresiewicz, W. (2015). The death of the artist - and the birth of the creative entrepreneur. The Atlantic. https://www.theatlantic.com/magazine/archive/2015/01/the-death-of-the-artist-and-the-birthof-the-creative-entrepreneur/383497/

Dutton, J. E., Morgan Roberts, L., \& Bednar, J. (2010). Pathways for positive identity construction at work: four types of positive identity and the building of social resources. Academy of Management Review, 35(2), 265-293. https://doi.org/10.5465/AMR.2010.48463334

Elstad, B., \& Jansson, D. (2020). From artist to manager - working conditions, career satisfaction, and professional identity among graduated arts management students. The Journal of Arts Management, Law, and Society, 50(3), 184-198. https://doi.org/10.1080/10632921.2020.1746717

Erat, S., Kitapçi, H., \& Akçin, K. (2020). Managerial perception and organizational identity: a comparative analysis. Sustainability, 12. https://doi.org/10.3390/su12062278

Fletcher, J., \& Olwyler, K. (1997). Paradoxical thinking: how to profit from your contradictions. BerrettKoehler Publishers, Inc.

Gerpott, F. H., Quaquebeke, Van N., Schlamp, S., \& Voelpel, S. C. (2019). An identity perspective on ethical leadership to explain organizational citizenship behavior: the interplay of follower moral identity and leader group prototypicality. Journal of Business Ethics, 156, 1063-1078. https://doi.org/10.1007/s10551-017-3625-0

Giraud Voss, Z., Cable, D. M., \& Voss, G. B. (2006). Organizational identity and firm performance: what happens when leaders disagree about "Who We Are?". Organization Science, 17(6), 741-755. https://doi.org/10.1287/orsc.1060.0218

Gołaszewska, M. (1984). Zarys estetyki. Wydawnictwo Naukowe PWN.

Gotsi, M., Andriopoulos, C., Lewis, M. W., \& Ingram, A. E. (2010). Managing creatives: paradoxical approaches to identity regulation. Human Relations, 63(6), 781-805. https://doi.org/10.1177/0018726709342929

Gray, D. E., Gabriel, Y., \& Goregaokar, H. (2015). Coaching unemployed managers and professionals through the trauma of unemployment: derailed or undaunted? Management Learning, 46(3), 299-316. https://doi.org/10.1177/1350507614532752

Grigoryan, L. K., \& Kotova, M. V. (2018). National identity management strategies: do they help or hinder adoption of multiculturalism in Russia? Psychology in Russia: State of the Art, 11(3), 18-35. https://doi.org/10.11621/pir.2018.0302

Hallier, J. (2004). Embellishing the past: middle manager identity and informality in the implementaion of new technology. New Technology, Work and Employment, 19(1), 43-62. https://doi.org/10.1111/j.1468-005X.2004.00127.x

Hay, A. (2014). I don't know what I am doing!": surfacing struggles of managerial identity work. Management Learning, 45(5), 509-524. https://doi.org/10.1177/1350507613483421

Hermes, J., Koch, K., Bakhuisen, N., \& Borghuis, P. (2017). this is my life: the stories of independent workers in the creative industries in the Netherlands. Javnost - The Public: Journal of the European Institute for Communication and Culture, 24(1), 87-101. https://doi.org/10.1080/13183222.2017.1280892 
Hospers, G.-J., \& Dalm, van R. (2005). How to create a creative city? The viewpoints of Richard Florida and Jane Jacobs. Foresight, 7(4), 8-12. https://doi.org/10.1108/14636680510611796

Hracs, B. J. (2015). Cultural intermediaries in the digital age: the case of independent musicians and managers in Toronto. Regional Studies, 49(3), 461-475.

https://doi.org/10.1080/00343404.2012.750425

Ibarra, H. (2004). Working identity: unconventional strategies for reinventing your career. Harvard Business School Press.

Joffe, M., \& MacKenzie-Davey, K. (2012). The problem of identity in hybrid managers: who are medical directors? International Journal of Leadership in Public Services, 8(3), 161-174. https://doi.org/10.1108/17479881211282649

Kačerauskas, T. (2018). Indices of creative economy: critique of R. Florida’s creativity indices. Economics and Sociology, 11(4), 280-288. https://doi.org/10.14254/2071-789X.2018/11-4/18

Khazraee, E., \& Novak, A. N. (2018). Digitally mediated protest: social media affordances for collective identity construction. Social Media and Society, 4(1), 1-14. https://doi.org/10.1177/2056305118765740

Knight, E., \& Paroutis, S. (2017). Becoming salient: The TMT leader's role in shaping the interpretive context of paradoxical tensions. Organization Studies, 38(3-4), 403-432. https://doi.org/10.1177/0170840616640844

Kunrath, K., Cash, Ph., \& Kleinsmann, M. (2020). Social- and self-perception of designers' professional identity. Journal of Engineering Design, 31(2), 100-126. https://doi.org/10.1080/09544828.2019.1676883

Martin, R., Florida, R., Pogue, M., \& Mellander, Ch. (2015). Creativity, clusters and the competitive advantage of cities. Competitiveness Review, 25(5), 482-496. https://doi.org/10.1108/CR-07-2015-0069

Masso, A. (2010). Geographical perspective on identity construction: identification strategies of Russian youth in Estonia. The International Journal of Interdisciplinary Social Sciences: Annual Review, 5(6), 51-62. https://doi.org/10.18848/1833-1882/CGP/v05i06/51763

McNeill, L., \& Venter, B. (2019). Identity, self-concept and young women's engagement with collaborative, sustainable fashion consumption models. International Journal of Consumer Studies, 43(4), 368-378. https://doi.org/10.1111/ijcs.12516

Mochalova, N. Y. (2020). Personal'naja identichnost' hudozhnika kak uslovie i rezul'tat tvorchestva v iskusstve. Jetnicheskaja kul'tura, 2(3), 62-67.

Netting, F. E., \& Williams, F. G. (1996). Case manager-physician collaboration: implications for professional identity, roles, and relationships. Health and Social Work, 21(3), 216-224. https://doi.org/10.1093/hsw/21.3.216

Putnam, L. L. (2015, 2-4 July). Moving beyond "both-and" approaches: alternative strategies for managing paradoxical tensions. In paper presented at the Annual European Group on Organizational Studies Colloquium. Athens, Greece.

Reedy, P. (2008). Mirror, mirror, on the wall: reflecting on the ethics and effects of a collective critical management studies identity project. Management Learning, 39(1), 57-72. https://doi.org/10.1177/1350507607085978

Saavedra Llamas, M., \& Grijalba de la Calle, N. (2020). The creative cinematographic process at the service of national identity: Pedro Almodóvar and the promotion of Spanish stereotypes. Creativity Studies, 13(2), 369-386. https://doi.org/10.3846/cs.2020.8563

Schediwy, L., Bhansing, P. V., \& Loots, E. (2018). Young musicians' career identities: do bohemian and entrepreneurial career identities compete or cohere? Creative Industries Journal, 11(2), 174-196. https://doi.org/10.1080/17510694.2018.1489197

Schein, E. H. (2001). The role of art and the artist. Reflections, 2(4), 81-83. https://doi.org/10.1162/152417301750385495 
Sethi, A., Mishra, N., \& Dash, M. (2010). Social identity crisis amongst employees in mergers and acquisitions. SSRN. https://doi.org/10.2139/ssrn.1588565

Sims, D. (2003). Between the millstones: a narrative account of the vulnerability of middle managers' storying. Human Relations, 56(10), 1195-1211. https://doi.org/10.1177/00187267035610002

Stasiulis, N. (2017). The idea of the creative society and the development of creative industries. Economics and Sociology, 10(2), 217-226. https://doi.org/10.14254/2071-789X.2017/10-2/16

Sveningsson, S., \& Alvesson, M. (2003). Managing managerial identities: organizational fragmentation, discourse and identity struggle. Human Relations, 56(10), 1163-1193. https://doi.org/10.1177/00187267035610001

Szostak, M. (2020). Creativity and artistry in organ music. The Organ, 391, 24-31.

Szostak, M., \& Sulkowski, L. (2020a, 1-2 April). Kitsch in management: characteristic forms, carriers and propagators. In K. S. Soliman (Ed.), Education excellence and innovation management: a 2025 vision to sustain economic development during global challenges. 35th International Business Information Management Association Conference (IBIMA 2020) (pp. 7584-7598). Seville, Spain. International Business Information Management Association.

Szostak, M., \& Sułkowski, Ł. (2020b). Manager as an artist: creative endeavour in crossing the borders of art and organizational discourse. Creativity Studies, 13(2), 351-368. https://doi.org/10.3846/cs.2020.11373

Tatarkiewicz, W. (2020). Historia estetyki. Tom I. Wydawnictwo Naukowe PWN.

Tchouikina, S. (2010). The crisis in Russian cultural management: Western influences and the formation of new professional identities in the 1990s-2000s. The Journal of Arts Management, Law, and Society, 40(1), 76-91. https://doi.org/10.1080/10632921003603950

Thornton, A. (2011). Being an artist teacher: a liberating identity? The International Journal of Art and Design Education, 30(1), 31-36. https://doi.org/10.1111/j.1476-8070.2011.01684.x

Vincent, L. C., \& Kouchaki, M. (2014). Creative, rare, entitled, and dishonest: how commonality of creativity in one's group decreases an individual's entitlement and dishonesty. Academy of Management Journal, 59(4), 1451-1473. https://doi.org/10.5465/amj.2014.1109

Warhurst, R., \& Black, K. (2017). What do managers know? Wisdom and manager identity in later career. Management Learning, 48(4), 416-430.

Watson, T. J. (1994). In search of management: culture, chaos and control in managerial work. Routledge. https://doi.org/10.1177/1350507616679346

Watson, T. J. (2009). Narrative, life story and manager identity: a case study in autobiographical identity work. Human Relations, 62(3), 425-452. https://doi.org/10.1177/0018726708101044

White, H. C. (1992). Identity and control: a structural theory of social action. Princeton University Press.

Wolf, C. (2019). Not lost in translation: managerial career narratives and the construction of protean identities. Human Relations, 72(3), 505-533. https://doi.org/10.1177/0018726718778094

Yazar, T., \& Arifoglu, G. (2012). A research of audio visual educational aids on the creativity levels of 4-14 year old children as a process in primary education. Procedia - Social and Behavioral Sciences, 51, 301-306. https://doi.org/10.1016/j.sbspro.2012.08.163

Zachorowska-Mazurkiewicz, A., \& Sierotowicz, T. (2017). Women, men and creativity in higher education sector - comparative studies of leading EU and ECE countries. Journal of International Studies, 10(3), 105-119.

Zambrell, K. (2016). Managers' identity construction at work: artistic interventions as triggers for identity work. Organizational Aesthetics, 5(2), 34-67. https:/doi.org/10.14254/2071-8330.2017/10-3/8

Zocche, L., Carísio de Paula, I., Kunrath, S. E., Milani Martins, V. L., \& Lermen, F. H. (2018). variables that influence creativity in perception of professionals: a case study in innovative Brazilian companies. Thinking Skills and Creativity, 29, 170-184. https://doi.org/10.1016/j.tsc.2018.07.002 